\title{
OBITUARY
}

\section{William HenRy Dines}

$$
1855 \text { - } 1927 \text {. }
$$

William Henry Dines, an Honorary Fellow of the Royal Aeronautical Society, was one of the leading authorities on the upper air, to the study of which he devoted a great part of his life. The exploration of the upper air was carried out by $\mathrm{Mr}$. Dines mainly by the use of kites. Before $1900 \mathrm{Mr}$. Dines had become widely known as a meteorologist in connection with his work on the pressure of winds, and from his work came the pressure tube anemometer, which marked a very definite advance in the measurement of wind. Mr. Dines made nearly all his own instruments, among which may be mentioned the anemometer, sunshire recorder, barograph, thermograph, kite and balloon meteorographs and instruments for measuring solar and terrestrial radiation.

Mr. Dines became a member of the Royal Meteorological Society in 1881 and its President in 1901 and 1902 . It was in his first year as President that he was elected an Honorary Fellow of the Royal Aeronautical Society. In 1905 he was elected a Fellow of the Royal Society. Since he became an Honorary Fellow of the Royal Aeronautical Society, Mr. Dines wrote a number of important articles for the Journal, including "The Practical Application of Meteorology to Aeronautics " in 191 1 , a subject on which he also lectured before the Society in 1918 .

Himself the son of a meteorologist, Mr. Dines leaves two sons, both of whom are on the staff of the Meteorological Office. He leaves behind him a record of achievement which is not yet fully known or adequately appreciated, due largely to his own retiring disposition.

\section{Sir Mackenzie Dalziel Chalmers}

$$
1847-1927 .
$$

Sir Mackenzie Dalziel Chalmers, who died on December 22nd, 1927, was a great public servant. Born on February $7^{t h}, 1847$, he was the son of the Rev. F. S. Chalmers, D.D., who served some twenty years in the army before he took holy orders. He wos educated at King's College, London, and Trinity College, Oxford. After leaving Oxford he entered the Indian Civil Service and served in India until 1872 , when he returned home to practise at the Bar. $\mathrm{He}$ was County Court Judge at Birmingham from 1884 to 1896 , when he returned to India as the Law Member of the Viceroy's Council. He left India again in 1899 to become Assistant Parliamentary Counsel to the Treasury, and from 1903 to 1908 he was the Permanent Under-Secretary of the Home Office. He was created C.S.I. in 1898, C.B. in 1904 and K.C.B. in 1906.

Such is a brief, but not exhaustive, record of the achievements of a distinguished man who during the closing years of his life was an honoured member of the Royal Aeronautical Society, and took an active interest in its affairs. It is difficult to say what first drew him to the Society, unless it was the natural instinct of one whose mind never aged to associate himself with a modern enterprise which, above all others, depends on youth for its practical success. Certainly he had had some previous, and not altogether pleasant, association with aeronautics as a 